Ciencias

Veterinarias
Rev. Ciencias Veterinarias, Vol. 37, Nº 3, [18-19], E-ISSN: 2215-4507

First Symposium on Regenerative Medicine and Nanotechnology, Costa Rica 2019 DOI: https://doi.org/10.15359/rcv.37-3.5

URL: http://www.revistas.una.ac.cr/index.php/veterinaria/index

\title{
Pathogenesis and prevention strategies for equine tendinopathy
}

\section{Patogenia y estrategias de prevención de la tendinopatía equina}

\author{
Roger K.W. Smith ${ }^{1}$ \\ 1 Dept. of Clinical Sciences and Services, The Royal Veterinary College, London, UK. Email: rksmith@rvc.ac.uk.
}

\begin{abstract}
Equine tendinopathy arises through two main mechanisms - external trauma or overstrain injury. The pathogenesis of the former is straight forward and prevention relies on avoiding risk factors for palmar/plantar lacerations and protecting the tendons through the use of boots. For over-strain injuries, these mostly arise from overloading of the distal limb resulting in mid-substance tearing of the digital flexor tendons or borders tears of the deep digital flexor tendon within the confines of the digital sheath and navicular bursa. While some of these injuries may be spontaneous injuries associated solely with overload (such as the intra-thecal injuries of the deep digital flexor tendon), it is widely accepted that most overstrain injuries of the superficial digital flexor tendon (and suspensory ligament) occur as a result of accumulated microdamage which predisposes the tendon to over-strain injury. The mechanisms of this accumulated microdamage are poorly understood but probably relate to the effect of high impact loading of the tendon, sustained during normal exercise, which drives degradative changes in the tendon fascicles (Dudhia et al. 2007) and, in particular, the interfascicular matrix (endotenon) that allows the fascicles to slide past one another as a mechanism for the spring-like extension of the tendon under load (Thorpe et al. 2013). This is compounded by the lack of adaptive remodelling in adult tendon (Smith et al. 2002). This subclinical damage makes the tendon prone to sudden tearing of the tendon matrix during normal exercise, the risk of which is increased by factors such as the firmness of the ground, weight, speed, and fatigue. Strategies for prevention of injury rely on identifying at risk individuals through more sensitive monitoring of tendon health, maximising the quality of tendon during growth using carefully tailored 'conditioning' exercise regimes (Smith \& Goodship 2008), reducing the degeneration induced by normal training and competition, and avoiding high risk factors for the initiation of the clinical injury.
\end{abstract}

\section{References}

Dudhia, J., Scott, C.M., Draper, E.R., Heinegard, D., Pitsillides, A.A. \& Smith, R.K. 2007. Aging enhances a mechanically-induced reduction in tendon strength by an active process involving matrix metalloproteinase activity. Aging Cell 6(4): 547-556. DOI: 10.1111/j.1474-9726.2007.00307.x

Smith, R.K., Birch, H.L., Goodman, S., Heinegard, D. \& Goodship, A.E. 2002. The influence of ageing and exercise on tendon growth and degeneration--hypotheses for the initiation and prevention 
Ciencias

Veterinarias

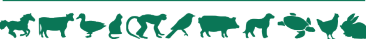

Rev. Ciencias Veterinarias, Vol. 37, Nº 3, [18-19], E-ISSN: 2215-4507

First Symposium on Regenerative Medicine and Nanotechnology, Costa Rica 2019 DOI: https://doi.org/10.15359/rcv.37-3.5

URL: http://www.revistas.una.ac.cr/index.php/veterinaria/index

of strain-induced tendinopathies. Comp. Biochem. Physiol. A. Mol. Integr. Physiol. 133(4): 10391050. DOI: $10.1016 / S 1095-6433(02) 00148-4$

Smith, R.K. \& Goodship, A.E. 2008. The effect of early training and the adaptation and conditioning of skeletal tissues. Vet. Clin. North. Am. Equine Pract. 24(1): 37-51. DOI: 10.1016/j.cveq.2007.11.005

Thorpe, C.T., Udeze, C.P., Birch, H.L., Clegg, P.D. \& Screen, H.R. 2013. Capacity for sliding between tendon fascicles decreases with ageing in injury prone equine tendons: a possible mechanism for age-related tendinopathy? Eur. Cell Mater. 25: 48-60. DOI: 10.22203/eCM 